\title{
A relevância de produzir conhecimento social e científico sobre o comportamento humano no trânsito ${ }^{1}$
}

\author{
Fabíola Garcia da Silva \\ Fundação Educacional Hansa Hammonia \\ Carla Giovana Dagostin \\ Universidade do Sul de Santa Catarina
}

$\mathrm{C}$ onhecer aspectos do comportamento humano no trânsito é uma necessidade social e cientifica, visto que cada vez mais as condições de transporte, deslocamento e circulação humana de um modo geral têm determinado significativamente a qualidade de vida e trabalho das pessoas. Com essa preocupação, Maria Helena Hoffmann, Roberto Moraes Cruz e João Carlos Alchieri, organizadores do livro Comportamento humano no trânsito, apresentam, juntamente com outros autores e pesquisadores, um conjunto de pesquisas e reflexões críticas sobre aspectos que constituem o sistema de trânsito, instigando os leitores ao processo de conhecer e desenvolver estratégias de intervenção progredindo social e cientificamente na qualidade do exercício profissional dos psicólogos no trânsito. O surgimento desta coletânea vem suprir a carência de divulgação do conhecimento acumulado durante décadas pela Psicologia do Trânsito no Brasil e do quanto ainda precisa ser investigado. $\mathrm{O}$ livro, desde a sua publicação no ano de 2003, com segunda impressão em 2004, revela-se essencial para a compreensão da história da Psicologia do Trânsito, dos fenômenos já pesquisados no contexto do sistema de trânsito, das temáticas do século XXI e perspectivas de estudo sobre o comportamento humano no trânsito no Brasil.

A obra apresentada é destinada a leitores interessados em conhecer os obstáculos e desafios que circundam as ciências do comportamento humano no trânsito, bem como as estratégias de intervenções nesse campo de atuação dos profissionais da Psicologia. Em cada capítulo, os autores, numa linguagem clara e precisa, vão despertando reflexões sobre o sistema de trânsito à comunidade de profissionais, principalmente psicólogos, professores, pesquisadores e alunos das diversas ciências do trânsito.

O livro inicia-se com a evolução da Psicologia do Trânsito no Brasil e sinteticamente a trajetória profissional dos psicólogos. Uma das atividades pioneiras desses profissionais no país foi a avaliação das dimensões psicológicas para dirigir por meio de técnicas de avaliação psicológica. A consolidação da Psicologia do Trânsito como disciplina científica marcou o início dos estudos da interdisciplinaridade. Foram também abordados a aprovação do Código de Trânsito Brasileiro e a demonstração da sensibilidade da sociedade e dos próprios psicólogos sobre as políticas públicas de saúde, educação e segurança associadas à circulação humana.

A circulação humana é realizada no meio ambiente. O ser humano não apenas vive no ambiente, mas pertence a ele. Essa interação permite compreender a interface do ambiente, trânsito e psicologia. O ambiente do sistema de trânsito exige do participante algumas condições psicológicas fundamentais para o convívio. No livro, os autores apresentam as interfaces do ambiente, trânsito e psicologia, e a interlocução da Psicologia Ambiental com as intervenções dos psicólogos do trânsito. A contribuição da Psicologia Ambiental para a área de conhecimento da Psicologia do Trânsito é relevante, visto a primeira aprofundar nos conhecimentos sobre a interação entre comportamento e ambiente físico, natural e/ ou construído.

As intersecções de outras áreas de conhecimento ampliam a atuação dos profissionais no alcance dos objetivos almejados. Uma das intervenções importantes e ainda insuficiente dos profissionais de Psicologia é a educação para o trânsito. Os autores destacam que a educação para o trânsito é um compromisso social e político de todos os cidadãos, focando a educação ética-social, integrando o homem, o meio ambiente e a realidade social. Os autores ainda apresentam algumas estratégias de atuação na área da educação, tendo como objetivo contribuir com criações de atitudes, comportamentos e pautas de conduta da população alvo, seja condutor, pedestre ou passageiro. As ações de políticas públicas estão intimamente relacionadas às necessidades de articular conhecimentos produzidos e comportamento humano. Para que essa integração aconteça, ações educativas são essenciais para a promoção da consciência cidadã em crianças, jovens, adultos e idosos, auxiliando na adaptação de comportamentos adequados e favorecendo a construção de responsabilidades coletivas para melhorar o relacionamento humano no trânsito. 
No aprimoramento da intervenção dos profissionais, há necessidade de produzir conhecimento sobre aspectos do comportamento humano no trânsito, tanto da atividade de dirigir e dos profissionais, quanto dos processos ambientais, sociais, econômicos, tecnológicos, fisiológicos e psicológicos. Para isso, a metodologia de pesquisa no trânsito, também abordada no livro, contribui para auxiliar na sistematização do conhecimento necessário acerca dos aspectos que envolvem a circulação humana, fornecendo subsídios para responder a pergunta: quais procedimentos necessários para realizar pesquisas de fenômenos que acontecem no trânsito? Os autores demonstraram as etapas de elaboração de pesquisa, desde a escolha do tema, delimitação de problema, método, até tratamento dos resultados. No livro são apresentados também exemplos de problemas de pesquisa a serem investigados, instigando assim os leitores a outras necessidades de sistematização de conhecimento sobre trânsito. O processo de conhecer as etapas da pesquisa possibilita compreender os conhecimentos já produzidos, bem como motivar a investigação de outros fenômenos, principalmente da atividade profissional.

As avaliações das dimensões psicológicas para dirigir realizada pelos psicólogos peritos examinadores de trânsito são abordadas em vários capítulos do livro, motivando o aperfeiçoamento sobre essa temática. Há pesquisas em que os fenômenos investigados foram as competências sociais e técnicas desses profissionais, considerações sobre a prática profissional, a percepção dos psicólogos sobre a atividade de avaliar os condutores e a caracterização das técnicas e dos instrumentos psicológicos. Os resultados dos estudos apresentados no livro possibilitam a continuidade de avanços no entendimento de outras problemáticas e fenômenos necessários à atividade profissional e área de conhecimento.

O comportamento humano dos participantes do sistema de trânsito associados aos acidentes é fenômeno também apresentado no livro. Os aspectos investigados são tanto as causas de acidentes, os fatores humanos envolvidos nesse evento, quanto às atividades de intervenções realizadas com os condutores acidentados. A preocupação também com o atropelamento infantil e com a redução dos acidentes por meio da participação dos psicólogos e de outros profissionais de áreas afins faz o leitor refletir que o trânsito é um fenômeno eminentemente social, necessitando buscar estratégias para ampliar o campo de intervenção.

O livro Comportamento humano no trânsito pode ser considerado um marco na Psicologia do Trânsito no Brasil, visto reunir sistematizações científicas e apresentar discussões com especialistas de fenômenos do trânsito. Esta obra concentra as produções de conhecimentos científicos e sociais que circundam a Psicologia do Trânsito no Brasil, sendo de vital importância a leitura e compreensão dos estudos pelos profissionais que direta ou indiretamente intervêm ou estudam os fenômenos psicológicos associados à mobilidade humana. A mensagem dos autores do livro é de que a Psicologia como ciência pode contribuir para o processo de conhecer e de produzir conhecimentos sobre os fatores que interferem na circulação humana.

Nota

1. Resenha do livro Comportamento Humano no Trânsito, coletânea organizada por Maria Helena Hoffmann, Roberto Moraes Cruz \& João Carlos Alchieri, publicado em 2003, pela Editora Casa do Psicólogo.

Fabíola Garcia da Silva, mestre em Psicologia pela Universidade Federal de Santa Catarina, é professora no Curso de Psicologia da Fundação Educacional Hansa Hammonia. Endereço para correspondência: Rua Domingos Pedro Hermes, 289 (Barreiros); São José, SC; CEP: 88.111-330. E-mail: fabiola@merisio.com.br ou psicologafabiola@bol.com.br Carla Giovana Dagostin, mestre em Psicologia pela Universidade Federal de Santa Catarina, psicóloga perita examinadora de trânsito do DETRAN de Santa Catarina. 